\title{
Pengaruh Terapi Sensori Integrasi pada Anak Autis yang Mengalami Gangguan Sensori di Pusat Layanan Autis Provinsi Bangka Belitung
}

\section{Wahyu Kurniawan}

IAIN Syaikh Abdurrahman Siddik Bangka Belitung, Indonesia wahyulapter@gmail.com

\section{Merlinda Juvita}

IAIN Syaikh Abdurrahman Siddik Bangka Belitung, Indonesia merlindajuvita@gmail.com

\begin{abstract}
This study focuses on determining whether an influence of the application of sensory integration in autistic children in an autism service center of the Bangka Belitung island province. The hypothesis proposed is that there is a difference between before and after sensory integration. Subjects before being given sensory integration experienced a level of sensory disturbance that tended to increase compared to before being given treatment. The design used in this study is a single case study in the form of the effect of giving sensory integration therapy treatment. The analytical method used is analysis, visual inspection, interviews and non-parametric observation and analysis (Wilcoxon). The results of hypothesis testing on this therapy are $Z=0.034$ ( $p>0.05)$. Based on the analysis, it means that there is a difference in the decrease in the frequency of sensory disturbances between before and after sensory integration therapy in students in the autistic service center of Bangka Belitung province.
\end{abstract}

Keywords; Autism, Sensory Integration, Sensory Disorder.

\begin{abstract}
Abstrak
Penelitian ini bertujuan untuk menentukan apakah ada pengaruh penerapan sensori integrasi pada anak autis di Pusat Layanan Autis Provinsi Kepulauan Bangka Belitung. Adapun hipotesis yang diajukan adalah ada perbedaan antara sebelum dan sesudah pemberian sensori integrasi. Subjek sebelum diberikan sensori integrasi mengalami tingkat gangguan sensori yang cenderung meningkat dibandingkan dengan sebelum diberikan perlakuan. Desain yang digunakan dalam penelitian ini adalah single case study berupa pengaruh pemberian perlakuan terapi sensori integrasi. Metode analisis yang digunakan analisis, visual inspection, wawancara serta observasi dan analisis non parametrik (Wilcoxon). Hasil uji hipotesis pada terapi ini ialah $Z$ sebesar =0,034 ( $p>0,05)$, Berdasarkan analisis tersebut berarti bahwa ada perbedaan penurunan frekuensi gangguan sensori antara sebelum dan sesudah diberikan terapi sensori integrasi pada peserta didik di Pusat layanan autis provinsi Bangka belitung.
\end{abstract}

Kata kunci; autis, sensori integrasi, gangguan sensori.

Received: 15-06-2019; accepted: 10-07-2019; published: 18-07-2019 


\section{A. Pendahuluan}

Anak berkebutuhan khusus (ABK) atau penyandang disabilitas merupakan bagian dari anak Indonesia yang perlu mendapatkan perhatian dan perlindungan khusus oleh pemerintah Indonesia, masyarakat, dan keluarga. Upaya perlindungan dan penanganan pada anak berkebutuhan khusus adalah langkah yang bisa diberikan guna anak ABK agar dapat bertahan hidup, tumbuh, berkembang secara optimal serta dapat berpartisipasi sesuai dengan kemampuan yang bisa dimilikinya. ${ }^{1}$ ABK atau anak berkebutuhan khusus adalah anak yang memerlukan pendidikan dan layanan khusus sehingga terlihat jelas adanya perbedaan antara anak satu dan lainnya yang meliputi salah satu diantaranya seperti ketidakmampuan dalam belajar, gangguan atensi, gangguan perilaku, keterbelakangan mental, hambatan pada fisik, gangguan pendengaran, gangguan komunikasi, traumabrain injury, dan gangguan autis. ${ }^{2}$

Peneliti akan memfokuskan pada salah satu gangguan tadi antara lain adalah anak dengan gejala Autis di Pusat Layanan Autis Provinsi kepulauan Bangka Belitung. Kata autis berasal dari bahasa Yunani “auto" berarti sendiri yang ditujukan pada seseorang yang menunjukkan gejala "hidup dalam dunianya sendiri". Istilah autis sendiri awal mula dikenalkan pada tahun 1943 oleh Leo Kanner seorang ilmuan kebangsaan Vienna. ${ }^{3}$ Anak dengan kecenderungan autis adalah anak yang mengalami gangguan neurologis yang kompleks yang mempengaruhi tidak hanya komunikasi tetapi juga bidang perkembangan lainnya. ${ }^{4}$ Autis diklasifikasikan sebagai gangguan spektrum dikarenakan setiap anak memiliki perbedaan dalam tingkat keparahan yang berbeda, adapun ciri cirinya antara lain adalah ketidakmampun dalam berhubungan sosial dengan orang lain, keterlambatan dalam perkembangan bahasa, adanya hambatan dalam pertumbuhan fisik, memiliki kesenangan dan daya tarik yang berlebihan pada objek tertentu, dan adanya perilaku yang bersifat streotipe atau berulang-ulang. ${ }^{5}$

1 Eko Suryani \& Badi'ah, Asuhan Keperawatan Anak Sehat \& Anak Berkebutuhan Khusus (Yogyakarta: Pustaka Baru Press, 2017), p. 207.

${ }^{2}$ Frieda Mangunsong, Psikologi dan pendidikan anak berkebutuhan khusus jilid 1 (Jakarta: LPSP3 UI, 2014), p. 3.

${ }^{3}$ Ibid., p. 166.

${ }^{4}$ Beverly Otto, Perkembangan Bahasa Pada anak Usia Dini (Jakarta: Kencana, 2015), p. 448.

5 Subyantoro, Gangguan Bahasa Mengenali Untuk Mengantisipasi sejak dini, (Jakarta: Ombak, 2013) p. 52-3. 
Senada dengan hal tersebut definisi lainnya pula sebagaimana yang dikemukakan oleh Santrock yang menjelaskan bahwa ciri-ciri autisme ditandai dengan adanya gangguan komunikasi verbal dan non verbal, masalah interaksi sosial, serta gangguan perilaku repetitif. ${ }^{6}$ Definisi lainnya dalam DSM-5 disebut sebagai Autism Spectrum Disorder (ASD) yaitu dikarakterisasikan sebagai defisit yang persisten dalam komunikasi dan interaksi sosial pada berbagai situasi, termasuk defisit hubungan timbal balik sosial, perilaku komunikatif non-verbal, dan ketrampilan mengembangkan, mempertahankan serta memahami hubungan. Sebagai tambahan atas defisit dari diagnosis ASD yaitu adanya pola perilaku minat yang terbatas, maupun aktivitas yang berulang. ${ }^{7}$

Anak dengan indikasi Autis atau ASD semakin hari semakin meningkat dari sisi jumlah. Hal ini sebagimana yang dikemukakan oleh National Information Center for Children and Youth with Disabilities (NICHCY) memperkirakan bahwa autisme dan PDD pada tahun 2000 mendekati 50-100 per 10.000 kelahiran. Sedangkan penelitian Frombonne menghasilkan prevalensi dari autisme beserta spektrumnya (Autism Spectrum Disorder/ASD) adalah: 60/10.000 - best current estimate dan terdapat 425.000 penyandang ASD yang berusia dibawah 18 tahun di Amerika Serikat. Di Inggris, data terbaru adalah: 62.6/10.000 ASD ${ }^{8}$.

Di Indonesia sendiri walaupun belum ada data pasti, merujuk pada Incidence dan prevalence ASD terdapat kurang lebih berjumlah 2.4 Juta dengan penambahan kurang lebih 500 orang pertahun. ${ }^{9}$ Mengenai jumlah anak autis di provinsi Kepulauan Bangka Belitung hingga kini belum ada data yang pasti namun disinyalir angka penderita autis semakin hari semakin meningkat hal ini dibuktikan berdasarkan dari angka statistik dari tahun 2015 hingga tahun 2018 yang menunjukkan jumlah peserta didik di Pusat Layanan Autis cenderung meningkat. ${ }^{10}$

Mengenai faktor penyebab autis sendiri hingga saat ini beberapa pakar berbeda pandangan namun adapun faktor diantara lain memiliki kecenderungan tinggi mengalami Brain Seizures dan defisit kognitif, pada keterangan disini dijelakan pula

\footnotetext{
${ }^{6}$ Jhon W. Santrock, Psikologi Pendidikan (Jakarta: Salemba Humanika, 2009) p. 265.

7 DSM-V

8 Buku panduan SPM PLA Indonesia.

${ }^{9}$ Diakses dari www.kemenppa.go.id

${ }^{10}$ Hasil wawancara dengan karyawan PLA Babel tanggal 11 Januari 2019
} 
ditemukan ukuran kepala anak dengan indikasi Autis cenderung lebih besar dari ukuran normal.11

Hal lain yang disinyalir menjadi penyebab adalah adanya pengaruh heriditas Penyebab lainnya pula seperti dikemukakan oleh Subyantoro ${ }^{12}$ antara lain adalah adanya vaksin yang mengandung Thimerosal, televisi, genetik, radiasi, folid Acid. Sedangkan Suryani \& Ba'diah menambahkan faktor lainnya antara lain, Faktor genetika, 80\% anak ASD dipengaruhi dengan adanya keluarga yang sama, kelainan kromosom, neurokimia, cidera otak, penyakit otak organik, serta lingkungan. ${ }^{13}$

Berbagai dampak yang dialami anak ASD ialah adanya hambatan dari sisi sensori hal ini sebagaimana yang dikemukakan oleh Ayers, apabila input sensori berfungsi tidak tepat, seseorang akan menginterpretasi dunia secara berbeda. Mispersepsi ini akan menimbulkan berbagai gangguan perilaku dan perkembangan. Sensori sendiri diterjemahkan sebagai suatu proses bagaimana cara otak menerima dan memproses pengalaman seseorang kedalam kehidupan yang nyata. ${ }^{14}$ Adapun masalah yang dihadapi anak autis antara lain hiposensitif sensori. Hipersensitif sensori adalah kondisi dimana stimulasi yang diterima CNS yang seharusnya cukup, namun dirasa berlebihan. Sehingga anak cenderung menolak atau proteksi diri. Sedangkan masalah lainnya adalah Hiposensitif sensori. Kondisi dimana stimulasi yang diterima CNS yang seharusnya cukup, namun dirasa kurang. Sehingga anak cenderung mencari stimulasi. Anak tampak aktif dan selalu bergerak. ${ }^{15}$

Berdasarkan hasil observasi serta pengukuran menggunakan sensory checklist di Pusat Layanan Autis adapun subjek yang diambil adalah hanya dua subjek hal ini dikarenakan waktu penerimaan subjek dan hasil pemeriksaan berdasarkan alat test terdapat tiga anak yang memiliki kecenderungan yang sama yang mengalami kecenderungan Autis yang belum mendapatkan program terapi, hal lain pula dikarenakan hasil pemeriksaan anak cenderung mengalami masalah pada area sensori

\footnotetext{
11 Mangunsong, Psikologi dan pendidikan anak berkebutuhan khusus, pp. 173-5.

12 Subyantoro, Gangguan Bahasa Mengenali Untuk Mengantisipasi sejak dini, (Jakarta: Ombak, 2013) p. 49-50.

13 Eko Suryani \& Badi'ah, Asuhan Keperawatan Anak Sehat \& Anak Berkebutuhan Khusus (Yogyakarta: Pustaka Baru Press, 2017), p. 210. 289.

${ }^{14}$ Ayres, Sensory Integration and the child (Los Angeles: Western Psycological Servive, 1979), p.

15 Dewi K. Utama, 'Terapi Sensori Integrasi untuk Anak-Anak dengan Gangguan Spectrum Autisme', Konferensi Internasional Autism ke-1 (2003), p. 74-6.
} 
yang sama seperti mengalami masalah pada area tactile, audiotory, vestibular yang cenderung hipersensitif. Adapun masalah yang ditemui pada tiap subjek ini seperti pada saat pemeriksaan pada area tactile, anak mengalami masalah pada saat diminta berjalan pada saat di papan tactile dimana respon subjek cenderung menolak. Hal lain pula ketika subjek diminta bermain pada kolam bola, subjek cenderung menolak dan cenderun tantrum. Dari sisi vestibular anak cenderung tidak dapat fokus diminta melaksanakan tugas yang diberikan, menghindari kontak mata. Sedangkan pada area auditori, ananda cenderung menolak apabila mendengarkan suara suara yang cenderung ramai seperti suara percakapan lebih dari dua orang, mendengarkan musik dengan instrumen yang lebih cepat.

Berbagai cara yang biasanya dilakukan untuk menangani masalah sensori pada anak autis antara lain adalah melalui terapi sensori integrasi. Sensori integrasi adalah suatu program yang dikembangkan oleh Ayres seorang terapis Okupasi. ${ }^{16}$ Sensori integrasi adalah suatu jenis keterapian yang bertujuan untuk memperbaiki sistem regulasi dan modulasi dari berbagai input sensori, memfasilitasi fungsi regulasi dan memperbaiki fungsi RAS, memfasilitasi proses dari berbagai input sensori dan membantu perkembangan praktis dan keterampilan untuk memecahkan masalah. Sensori Integrasi dibentuk berdasarkan penelitian neurofisiologi. Dasar teori SI adalah adanya plastisitas sistem syaraf pusat, perkembangan yang bersifat progresif, organisasi sistem, respon adaptif, serta dorongan dalam diri yang lebih adaptif. ${ }^{17}$

Sensori integrasi atau terapi indera indra biasanya akan menggarap kelima pancaindera, persendian, otot, fisik, untuk mendapatkan efek postif bagi penderita autis. Adapun program ini bisa dimunculkan dalam berbagai aktfitas seperti terapi fisik, olahraga dan pelatihan pendengaran dan tomatis, biasanya para terapis akan menggunakan ayunan, memberikan sentuhan tactil dan disesuaikan dengan kebutuhan anak autis. ${ }^{18}$

Hal lain pula sebagaimana yang dijelaskan oleh Waiman yang menjelaskan bahwa Sensori Integrasi merupakan proses keterapian dalam mengenal, mengubah, membedakan sensasi sensori untuk menghasilkan suatu respon baik pada bagian

\footnotetext{
16 Ibid.

17 Ibid.

18 Anjali \& Blaise, Parenting Anak dengan Autisme Solusi, Strategi dan Saran Praktis Untuk Membantu Keluarga Anda (Yogyakarta: Pustaka Pelajar, 2014), p.158-60.
} 
tactile, propioseptif, visual, audiotory, glustatory, vestibular. Dengan pemberian sensori integrasi secara perlahan dapat memperbaiki fungsi otak anak anak dengan gejala autism, sehingga perilaku anak ASD menjadi membaik dan lebih adaptif sehingga akan mudah menerima informasi, menyimak, memberikan respon dalam aktifitas kesehariannya. ${ }^{19}$

Salah satu asumsi dari SI didasari bahwa otak adalah suatu organ yang berfungsi secara integratif, tetapi terdiri dari stuktur yang terorganisir secara hirarkis, salah satu fungsi dari SI sendiri selain penjabaran di atas berfungsi menerima, menyaring dan memperhalus input-input sensorik sebelum melanjutkan input-input yang telah dintegrasikan ke korteks otak. Maka fokus korteks tergantung pada fungsi struktur subkortikal untuk mendapatkan input sensori yang terintegrasi, agar dapat dioleh dan dianalisa dengan baik, untuk menyimpan reaksi yang tepat terhadap input input sensori tersebut.

Terdapat beberapa bukti penelitian yang menjelaskan pengaruh sensori integrasi antara lain adalah penelitian yang dilakukan oleh Yahya, et al. yang dalam objek kajiannya memfokuskan pada kemampuan motorik kasar pada anak autis melalui media berjalan diatas garis, penelitian tersebut terbukti mempengaruhi adanya peningkatan kemampuan motorik anak autis. ${ }^{20}$ Sedangkan penelitian lainnya pula sebagaimana penelitian yang dilakukan oleh Tanawali, et al. yang berjudul peningkatan kemampuan taktil pada anak autis melalui terapi sensori integrasi, penelitian ini hanya terfokus pada satu kemampuan sensori saja yaitu taktil. Hasil dalam penelitian ini terbukti jelas bahwa adanya peningkatan kemampuan taktil pada anak autis melalui terapi SI. ${ }^{21}$

Berdasarkan keteraangan diatas adapun hipotesa yang diajukan peneliti adalah adanya pengaruh pemberian program Sensori Integrasi pada anak autis dengan gangguan sensori di pusat layanan autis provinsi bangka belitung. Adapun skema yang dibuat digambarkan sebagai berikut:

19 Dewi K. Utama, 'Terapi Sensori Integrasi untuk Anak-Anak dengan Gangguan Spectrum Autisme', p. 77.

20 Adam Yahya, Agung Kurniawan, \& Ahmad Samawi, 'Pengaruh Terapi Sensori Integrasi Terhadap Kemampuan Motorik Kasar Berjalan di Atas Garis Siswa Autis', Jurnal Ortopedagogia, vol. 1, no. 4, (2015), p. 325-9.

21 Nur Hafidzah Tanawali, Haerani Nur, Kurniati Zainuddin, 'Peningkatan Kemampuan Taktil pada Anak Autis melalui Sensori Integrasi,' Jurnal psikologi Talenta, vol. 3, no. 2 (2018), p. 64-74. 

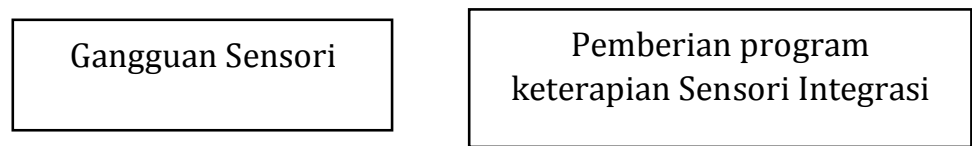

Penurunan Gangguan Sensori

\section{B. Metode Penelitian}

\section{Peserta Penelitian}

Subjek dalam penelitian ini adalah anak autis di Pusat Layanan Autis Provinsi Kepulauan Bangka Belitung sebanyak dua orang berdasarkan hasil pengukuran melalui DSM V, Chat, CHARS dan Sensori Profile. Adapun kegunaan dari DSM V, CHAT, CHARS digunakan sebagai cara menndiagnosa apakah subjek merupakan autis sedangkan sensori profile digunakan untuk mengetahui tingkat gangguan sensori pada anak autis. alasan lainnya mengapa diambil hanya tiga subjek, antara lain subjek memiliki masalah yang sama, subjek masuk dalam PLA dalam waktu penerimaan yang sama, subjek pula belum pernah mendapatkan terapi serta tingkat masalah yang dihadapi anak cenderung sama yaitu bermasalah pada area tactile, vestibular serta masalah pada auditori

\section{Desain Penelitian}

Pada penelitian ini menggunakan rancangan Small- $N$ design yang menggunakan desain A-B-A untuk mengetahui dari satu atau sedikit subjek secara lebih intensif ${ }^{22}$ Tujuan dari penelitian ini adalah untuk mengetahui pengaruh program sensori integrasi pada anak autis yang memiliki gangguan sensori dipusat layanan autis provinsi bangka belitung. Single case experimental design adalah desain penelitian untuk mengevaluasi efek dari suatu tritment dengan beberapa subjek dalam satu kelompok atau subjek yang diteliti adalah tunggal $(\mathrm{N}=2) \cdot{ }^{23}$ Dalam penelitian ini dilakukan pengukuran berulang pada variabel tergantung, baik sebelum pemberian intervensi maupun setelah pemberian intervensi yang berulang ulang dan membutuhkan waktu yang cukup lama. ${ }^{24}$ Pelaksanaan penelitian ini melibatkan fase pengukuran baseline (A),

22 Lihat Myers, A. \& Hansen C,H., Experimental Psychology, 5th edition (Wadsword: Thomson Learning; 2006).

${ }^{23}$ Kazdin, A. E., Sigel, T. \& Bass, 'Cognitive Problem-Solving Skill Training and Parent Management Training in the Treatment of Antisocial Behavioral in Children, Journal of Consulting and Clinical Psychology, vol. 57 (1992), p. 733-47.

${ }^{24}$ Lince, Aries, Bernadette, Psikologi Eksperimen (Jakarta: Indeks, 2011), p. 120. 
Fase pemberian intervensi (B), dan fase pengukuran setelah perlakuan ditarik (A). rancangan desain penelitian ini dapat digambarkan sebagai berikut:

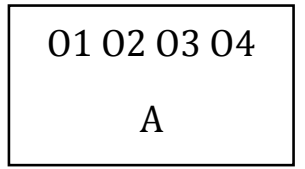

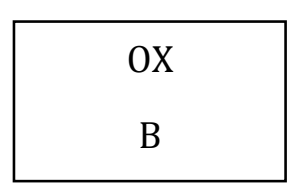

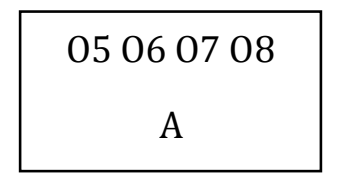

Keterangan:

01 : Pengukuran baseline 1

02 : Pengukuran baseline 2

03 : Pengukuran baseline 3

04 : Pengukuran baseline 4

OX : Fase Intervensi

05 : Pengukuran 1 setelah perlakuan dihentikan

06 : Pengukuran 2 setelah perlakuan dihentikan

07 : Pengukuran 3 setelah perlakuan dihentikan

08 : Pengukuran 4 setelah perlakuan dihentikan

Pengukuran baseline awal dan pengukuran setelah perlakuan dihentikan dilakukan masing-masing selama 12 kali dan dilaksanakan selama 12 kali pertemuan berturut-turut selama 3 bulan pertama. Untuk menyimpulkan kecenderungan data hasil observasi, setidaknya diperlukan tiga kali observasi untuk fase baseline pada grafik yang disajikan. ${ }^{25}$

\section{Metode Pengumpulan Data}

Metode pengumpulan data dilakukan dengan menggunakan wawancara dan pengamatan kepada subjek penelitian pada saat baseline, masa perlakuan, dan setelah diberikan perlakuan ditarik. Aspek aspek yang terkait dengan observasi yang dilakukan adalah berkaitan dengan gangguan sensori. Adapun panduan observasi ini dilakukan mengacu pada sensori profile. Aitem dalam observasi ini mengukur besaran frekuensi kemunculan respon atau target perilaku subjek maka peneliti menggunakan tanda tally (/) untuk jumlah perilaku yang muncul. Adapun metode yang lain ialah menggunakan wawancara dan observasi.

\section{Intervensi Penelitian}

Subjek dalam penelitian ini diberi perlakuan berupa program Terapi sensori integrasi terdiri dari beberapa materi tactile, vestibular, audiotory. Pemberian

${ }^{25}$ Lihat Barlow, D \& Hersen, M., Single-Case Experimental Design: Strategies for Studying Behavior Change, $2^{\text {nd }}$ Edition (New York: Pergamon Press, 1984) 
perlakuan dilakukan dalam 10 kali pertemuan selama tiga bulan dengan waktu 45 menit setiap sesi keterapian sebagaimana aturan dalam pelaksanaan keterapian di pusat layanan autis provinsi kepulauan Bangka Belitung yaitu masa penerimaan peserta didik selama 3 bulan. Adapun modul keterapian yang digunakan mengacu pada modul aturan pemberian program terapis yang disesuaikan dengan hasil asesmen.

\section{Metode Analisis Data}

Peneliti akan menggunakan metode analisis data dengan analisis visual atau visual inspection yaitu analisis data yang menginterpretasikan hasil melalui data grafik secara akurat dan bermakna dengan melihat perubahan yang terjadi dan melihat hubungan perubahan gangguan sensori dengan pemberian. Analisis statistik selanjutnya adalah dengan menggunakan teknik analisis Wilcoxon untuk menguji perbedaan gangguan sensori pada subjek sebelum diberikan terapi dan sesudah diberikan terapi.

\section{Hasil Penelitian}

\section{Analisis Visual Inspection}

Berikut data observasi berdasarkan hasil penilaian awal (Fase A 1) ketiga rater/observer dari sebelum pemberian terapi kognitif perilakuan hingga setelah pemberian terapi, adapun penjelasan dapat dijelaskan sebagai berikut:

a. Subjek ANR

Pengukuran dilakukan kepada subjek ANR melalui tiga rater, yang dilakukan melalui tiga tahapan pengukuran antara lain ialah pengukuran awal, pemberian intervensi dan pengukuran akhir. Adapun hasil pengukuran tersebut dijelaskan pada Tabel di bawah ini:

Tabel 1

\begin{tabular}{ccccc}
\hline \multirow{2}{*}{ Hari } & \multirow{2}{*}{ Waktu } & \multicolumn{3}{c}{ Skor total pengukuran awal (A1) } \\
\cline { 3 - 5 } & & Rater 1 & Rater 2 & Rater 3 \\
\hline 1 & $08.00-12.00$ & 20 & 24 & 24 \\
2 & $08.00-12.00$ & 19 & 15 & 15 \\
3 & $08.00-12.00$ & 20 & 18 & 18 \\
4 & $08.00-12.00$ & 20 & 20 & 20 \\
\hline
\end{tabular}


Pada sesi terapi data mentah yang peneliti temukan dijelaskan pada Tabel di bawah ini:

Tabel 2

\begin{tabular}{ccccc}
\hline \multirow{2}{*}{ Hari } & \multirow{2}{*}{ Waktu } & \multicolumn{3}{c}{ Skor total pengukuran tengah (B) } \\
\cline { 3 - 5 } & & Rater 1 & Rater 2 & Rater 3 \\
\hline 1 & $08.00-12.00$ & 10 & 10 & 10 \\
2 & $08.00-12.00$ & 6 & 6 & 6 \\
\hline
\end{tabular}

Berdasarkan keterangan di atas, maka terlihat bahwa terdapat penurunan frekuensi gangguan sensori oleh subjek. Sedangkan fase berikutnya ialah fase setelah intervensi yang diberikan kepada subjek. Adapun penjelasan data, dapat dilihat pada Tabel 3 di bawah ini:

Tabel 3

\begin{tabular}{ccccc}
\hline \multirow{2}{*}{ Hari } & \multirow{2}{*}{ Waktu } & \multicolumn{3}{c}{ Skor total pengukuran akhir (A2) } \\
\cline { 3 - 5 } & & Rater 1 & Rater 2 & Rater 3 \\
\hline 1 & $08.00-12.00$ & 13 & 13 & 13 \\
2 & $08.00-12.00$ & 12 & 12 & 12 \\
3 & $08.00-12.00$ & 12 & 12 & 13 \\
4 & $08.00-12.00$ & 12 & 12 & 12 \\
\hline
\end{tabular}

Berdasarkan data mentah dari ketiga hasil pengukuran sebelum intervensi (A1), selama pemberian Intervensi (B), dan setelah pemberian intervensi (A2). Maka dapat dicari hasil rerata skor total dari ketiga rater. Berikut ini analisis data yang dihasilkan dari hasil observasi yang ditampilkan dalam bentuk grafik. Setiap grafik mewakili rerata skor total dari ketiga rater berdasarkan tingkat gangguan sensori anak pada saat baseline awal (A1) selama 4 hari, pemberian intervensi (B) selama 2 hari, dan Baseline akhir (A2) selama 4 hari. 


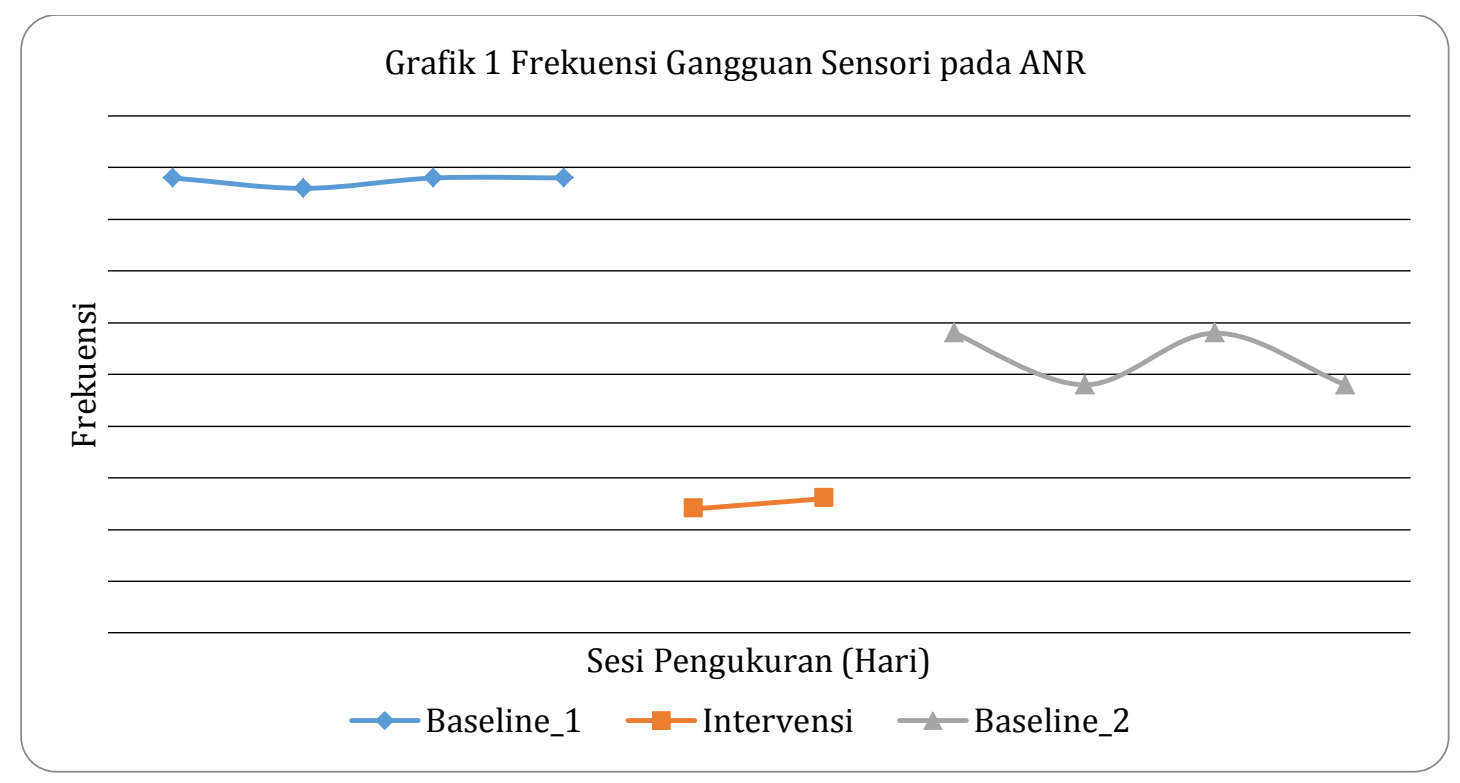

Berdasarkan data mentah dari ketiga hasil pengukuran sebelum intervensi (A1), selama pemberian Intervensi (B), dan setelah pemberian intervensi (A2). Maka dapat disimpulkan bahwa terdapat perubahan skor angka dari ketiga pengukuran di atas. Berdasarkan grafik pada gambar di atas tampak bahwa skor minimal frekuensi gangguan sensori pada pengukuran pada tahap awal (A1) ialah sebesar 16.3. Pada fase intervensi (B1) terlihat adanya perubahan grafik jika dibandingkan dengan sebelumnya ialah sebesar 6 , sedangkan pada fase pengukuran akhir nilai terendah ialah 12 . Sehingga dapat disimpulkan bahwa terdapat penurunan gangguan sensori pada subjek ANR baik sebelum dan sesudah diberikan intervensi.

b. Subjek IG

Pengukuran dilakukan kepada subjek IG melalui tiga rater, yang dilakukan melalui tiga tahapan pengukuran antara lain ialah pengukuran awal, pemberian intervensi dan pengukuran akhir. Adapun hasil pengukuran tersebut dijelaskan pada Tabel di bawah ini:

Tabel 4

\begin{tabular}{ccccc}
\hline \multirow{2}{*}{ Hari } & \multirow{2}{*}{ Waktu } & \multicolumn{3}{c}{ Skor total pengukuran awal (A1) } \\
\cline { 3 - 5 } & & Rater 1 & Rater 2 & Rater 3 \\
\hline 1 & $08.00-12.00$ & 15 & 15 & 14 \\
2 & $08.00-12.00$ & 14 & 14 & 15 \\
3 & $08.00-12.00$ & 15 & 15 & 14 \\
4 & $08.00-12.00$ & 15 & 15 & 14 \\
\hline
\end{tabular}

Pada sesi terapi data mentah yang peneliti temukan dijelaskan pada Tabel di bawah ini: 
Tabel 5

\begin{tabular}{ccccc}
\hline \multirow{2}{*}{ Hari } & \multirow{2}{*}{ Waktu } & \multicolumn{3}{c}{ Skor total pengukuran tengah (B) } \\
\cline { 3 - 5 } & & Rater 1 & Rater 2 & Rater 3 \\
\hline 1 & $08.00-12.00$ & 4 & 4 & 4 \\
2 & $08.00-12.00$ & 5 & 5 & 3 \\
\hline
\end{tabular}

Berdasarkan keterangan di atas, maka terlihat bahwa terdapat penurunan frekuensi gangguan sensori yang dialami oleh subjek. Sedangkan fase berikutnya ialah fase setelah intervensi yang diberikan kepada subjek. Adapun penjelasan data, dapat dilihat pada data di bawah ini:

Tabel 6

\begin{tabular}{ccccc}
\hline \multirow{2}{*}{ Hari } & Waktu & \multicolumn{3}{c}{ Skor total pengukuran akhir (A2) } \\
\cline { 3 - 5 } & & Rater 1 & Rater 2 & Rater 3 \\
\hline 1 & $08.00-12.00$ & 10 & 10 & 9 \\
2 & $08.00-12.00$ & 8 & 8 & 8 \\
3 & $08.00-12.00$ & 10 & 10 & 9 \\
4 & $08.00-12.00$ & 8 & 8 & 8 \\
\hline
\end{tabular}

Berdasarkan data mentah dari ketiga hasil pengukuran sebelum intervensi (A1), selama pemberian Intervensi (B), dan setelah pemberian intervensi (A2). Maka dapat dicari hasil rerata skor total dari ketiga rater. Berikut ini analisis data yang dihasilkan dari hasil observasi yang ditampilkan dalam bentuk grafik. Setiap grafik mewakili rerata skor total dari ketiga rater berdasarkan tingkat gangguan sensori anak pada saat autis baseline awal (A1) selama 4 hari, pemberian intervensi (B) selama 2 hari, dan Baseline akhir (A2) selama 4 hari.

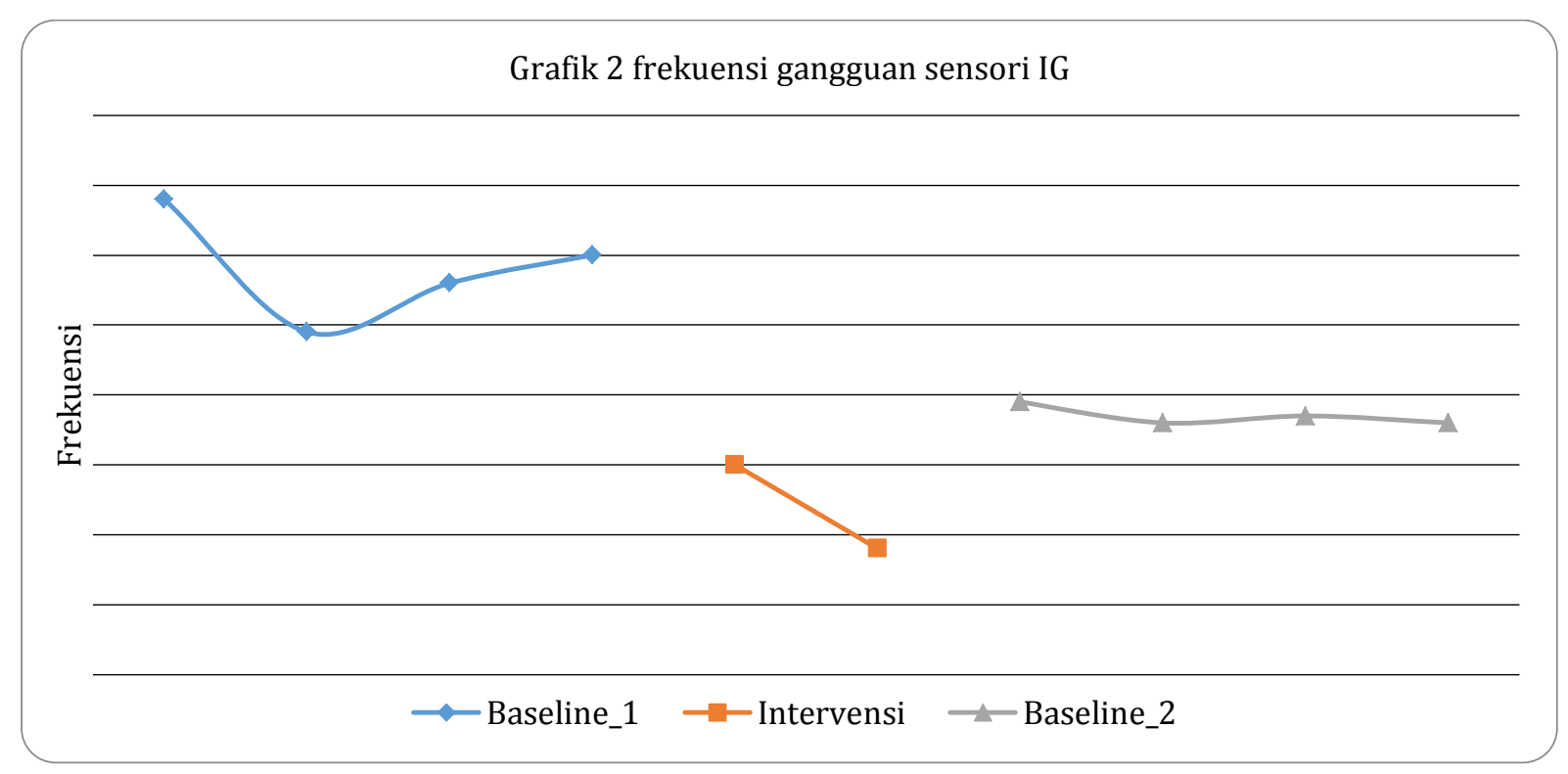


Berdasarkan data mentah dari ketiga hasil pengukuran sebelum intervensi (A1), selama pemberian Intervensi (B), dan setelah pemberian intervensi (A2). Maka dapat disimpulkan bahwa terdapat perubahan skor angka dari ketiga pengukuran di atas. Berdasarkan grafik pada gambar di atas tampak bahwa skor minimal frekuensi gangguan sensori pada pengukuran pada tahap awal (A1) ialah sebesar 14. Pada fase intervensi (B1) terlihat adanya perubahan grafik jika dibandingkan dengan sebelumnya ialah sebesar 4 sedangkan pada fase pengukuran akhir nilai terendah ialah 8. Sehingga dapat disimpulkan bahwa terdapat penurunan gangguan sensori pada IG baik sebelum dan sesudah diberikan intervensi.

\section{Analisis Deskriptif}

Analisis statistik selanjutnya adalah dengan menggunakan teknik analisis Wilcoxon Test untuk menguji gangguan sensori pada subjek sebelum diberikan terapi dan sesudah diberikan terapi. Adapun jumlah perolehan skor antara baseline awal dan akhir terlihat pada Tabel di bawah ini:

\begin{tabular}{c|c|c}
\multicolumn{3}{|c}{ Tabel 7 } \\
\hline Subjek & $\begin{array}{c}\text { Baseline awal } \\
\text { (A1) }\end{array}$ & Baseline akhir (A2) \\
\hline AND & 79 & 36 \\
IG & 59 & 43 \\
\hline
\end{tabular}

Hasil pengumpulan data pada baseline awal sebelum diberikan perlakuan menunjukan frekuensi gangguan perilaku menentang terendah 59 dan tertinggi 79 dengan rerata 69.50 Sedangkan pengumpulan data pada baseline akhir setelah perlakuan menunjukan frekuensi gangguan sensori terendah 36 dan tertinggi 43 dengan nilai rerata 39.25. Dari hasil analisis data didapatkan besaran $\mathrm{Z}=-1,826$ dengan nilai $\mathrm{p}=0,034<0,050$ sehingga dapat disimpulkan ada perbedaan signifikan frekuensi gangguan sensori pada anak autis di pusat layanan autis sebelum mendapatkan perlakuan.

\section{Pembahasan: Gangguan Sensori pada Anak Autis}

Anak dengan indikasi autis semakin hari semakin meningkat, penjabaran autis sendiri muncul sejak tahun 1800-1911 yang dikenalkan oleh psikiatri Swiss, Paul Bleule untuk mengkategorisasikan anak yang memiliki masalah dengan menarik diri dan 
gangguan interaksi sosial ${ }^{26}$. Ditahun 1943, Leo Kanne, psikiater pertama yang diakui sebagai psikiater anak yang menerbitkan sebuah investigasi tentang autis. Anjani dan Blaise sendiri menjelaskan anak dengan indikasi autis memiliki kelemahan pada sisi inderawi, dimana pengalaman inderawi pada anak autis biasanya tidak sama reaksinya, hal lain pula anak autis ditandai dengan stiming dimana anak ingin mengigit kuku, menepuk tangan, mengeraskan tubuh, menggelinding atau menjilat berulang. Hal lain pula cenderung memili perilaku yang cenderung bermasalah seperti ditandai dengan menarik diri, tidak merespon sosial, bermain sendiri indikasi lainnya ditandai dengan adanya minat yang tak lazim semisalkan ditandai dengan menyukai hal hal berulang dan itu itu saja tanpa diketahui penyebabnya dan anak biasanya cenderung melihat, memperatikan memutar mainan hingga mendekatkan matanya kemainan ${ }^{27}$.

Pembahasan ini akan difokuskan pada gangguan sensori pada anak autis. Masalah sensori pada tiap anak autis tidaklah sama. Pemrosesan indera pada anak autis dianggap memiliki kesulitan tertentu yang dibagi menjadi hiposensitif dan hipersensitif. Biasanya area gangguan ini meliputi pada area glustatori, tactile, propioseptif. Adapun penangan anak dengan gangguan sensori ini bisa diberikan berupa memberikan terapi sensori integrasi. Pemberian sensori integrasi pada anak autis dianggap cukup efektif dalam menangani gangguan tersebut. Adapun pemberian terapi ini ditentukan dengan berbagai cara tergantung pada masalah yang dialami oleh anak seperti masalah pada vestibular anak autis yang bisa diberikan melalui papan titian, bermain pada area kolam bola dilatih menggunakan bola bobat. Dengan pemberian program integrasi ditemukan dampak yang cukup signifikan antara sebelum dan sesudah diberikan keterapian SI. Anak yang belum diberikan SI menunjukkan gangguan sensori yang cukup tinggi dibandingan setelah diberikan program SI yang memiliki kecenderungan menurun.

26 Anjani \& Blaise, Parenting Anak dengan Autisme Solusi, Strategi, dan Saran Praktis Untuk Membantu Keluarga Anda, pp. 23-5.

27 Ibid. 
Mawaizh

Jurnal Dakwah dan Pengembangan Sosial Kemanusiaan

Vol. 10, no. 1 (2019), pp. 96-110.

DOI: https://doi.org/10.32923/maw.v10i1.786 


\section{DAFTAR PUSTAKA}

American Psychological Association, Diagnostic and Statistical Manual of Mental Disorder, Fifth Edition, 2013.

Anjali \& Blaise, Parenting Anak dengan Autisme: Solusi, Strategi dan Saran Praktis Untuk Membantu Keluarga Anda, Yogyakarta: Pustaka Pelajar, 2014.

Ayres, Sensory Integration and the Child, Los Angeles: Western Psycological Servive, 1979.

Barlow, D \& Hersen, M., Single-Case Experimental Design: Strategies for Studying Behavior Change, $2^{\text {nd }}$ Edition (New York: Pergamon Press, 1984

Buku panduan SPM PLA Indonesia.

Dewi K. Utama, 'Terapi Sensori Integrasi Untuk Anak Anak dengan Gangguan Spectrum Autism', Konferensi Internasional Autism ke-1 (2003).

Hari Peduli Autisme Sedunia Kenali Gejalanya, Pahami Keadaanya Diakses dari www.kemenppa.go.id pada tanggal 2 April 2018

Hasil wawancara dengan karyawan PLA Babel tanggal 11 Januari 2019

Kazdin, A. E., Sigel, T. \& Bass, 'Cognitive Problem-Solving Skill Training and Parent Management Training in the Treatment of Antisocial Behavioral in Children, Journal of Consulting and Clinical Psychology, vol. 57 (1992), p. 733-47.

Lince, et al., Psikologi Experiment, Jakarta: Indeks, 2011.

Mangunsong, Frieda, Psikologi dan Pendidikan Anak Berkebutuhan Khusus Jilid 1, Jakarta: LPSP3 UI, 2014.

Myers, A. \& Hansen C,H., Experimental Psychology, 5th Edition, Wadsword: Thomson Learning, 2006.

Otto Beverly, Perkembangan Bahasa Pada anak Usia Dini, Jakarta: Kencana, 2015.

Santrock, John W., Psikologi Pendidikan, trans. by Diana Angelica, Jakarta: Salemba Humanika, 2009.

Subyantoro, Gangguan Bahasa Mengenali Untuk Mengantisipasi Sejak Dini, Yogyakarta: Ombak, 2013.

Subyantoro, Gangguan Bahasa Mengenali Untuk Mengantisipasi Sejak Dini, Yogyakarta: Ombak, 2013.

Suryani, Eko \& Badi'ah, Asuhan Keperawatan Anak Sehat \& Anak Berkebutuhan Khusus, Yogyakarta: Pustaka Baru Press, 2017.

Tanawali, Nur Hafidzah, Nur, Haerani, Zainuddin, Kurniati, 'Peningkatan Kemampuan Taktil pada Anak Autis melalui Sensori Integrasi,' Jurnal psikologi Talenta, vol. 3, no. 2 (2018), p. 64-74.

Yahya, Adam, Kurniawan, Agung, \& Samawi, Ahmad, 'Pengaruh Terapi Sensori Integrasi Terhadap Kemampuan Motorik Kasar Berjalan di Atas Garis Siswa Autis', Jurnal Ortopedagogia, vol. 1, no. 4, (2015), p. 325-9. 